\title{
GOING BACK TO THE MANUSCRIPTS: AN INTERVIEW WITH LEA OLSAN
}

\section{Jonathan Roper}

In the first of what is to be hoped will be the first in a series of interviews with charms researchers about their scholarly life and work, we present an interview with Lea T. Olsan conducted remotely (via Skype) by Jonathan Roper in October 2020. Lea is one of the earliest members of the Committee for Charms, Charmers and Charming, having attended the first meeting in London almost twenty years ago. A medievalist and manuscript scholar, she moved from America to Cambridge almost twenty years ago. She and her husband Peter are familiar figures at our conferences.

\section{J.R.: How did you get started in charms research?}

I started charms research because a friend of mine (Suzanne Sheldon) was writing a dissertation on charms, and she wanted me to help her translate Latin charms which she had transcribed from the microfilms of manuscripts. And she was also developing the film in the bath-tub. And I had never read charms in manuscript before, and didn't know a thing about it then.

\section{J.R.: So what were you studying then?}

I took a degree in medieval studies and I had done Old English at Tulane [Louisiana], and we had met one another there. Working with her was my introduction to manuscripts. So everything I have learnt, I have learned by practice, off the seat of my pants. One time somebody at a conference said - well, these 
are hard to read, I wasn't trained as you were. And I laughed inside because I was never trained. It's a matter of going back to the manuscripts. Peter [her husband, the scholar of medicine, Peter Murray Jones] is very good at that of course, but he learnt the same way I did: he just started reading manuscripts.

I was teaching at the University of Louisiana at Monroe, and I could go to one meeting a year, so I chose to go (usually) to Kalamazoo [the American medieval studies congress]. And in the seventies and eighties, I put on sessions on medicine and magic there, including charms. And together the three of us, Suzanne Sheldon (Parnell, as she became), and another friend from Tulane, Patricia Giangrosso, conceived of an index of charms in medieval manuscripts ${ }^{1}$. Suzanne left the profession and changed her life, so she gave it up. And so did Patricia. So I'm the one that kept on doing charms forever. And we'd done a lot of work on it in a handwritten bespoke computer program, but the computer platform disappeared. It still chases me. People have asked me, you have asked me, for my index: it doesn't exist! I kept on working on charms, but I did not want to proceed with making an index after the computer platform disappeared. I wanted to work on charms, I didn't want just to make a list.

\section{J.R.: So what in your view would have been the benefit of an index?}

Just opening up this subject to everybody. And getting people to look at the texts.

\section{J.R.: And the difference between an index and a list?}

We were not going to transcribe the whole charm. We were going to locate charms in texts with key words and incipit to the text and incipit to the incantations. But unless they were very short they were never going to be fully transcribed.

\section{J.R.: So it was going to be a bit like the Index of Middle English Verse?}

Yes, but purely for charms. But I refused to just make an index. I was the one who decided not to do it because I'm the only one left of the original three still in this field, and I wanted to think more about the charms in the manuscripts.

\section{J.R.: But to go back a little, what aspects did your charms talks at Kala- mazoo cover?}

Mainly charms and medicine. Usually charms for healing. In the eighties, I did Latin charms from manuscripts in the fourteenth and fifteenth centuries. Eventually that came out much later in that corpus chapter in the book you 
edited $^{2}$. And things like that Arcus paper ${ }^{3}$, which was my first charms article, I gave at Kalamazoo.

\section{J.R.: Lots of those papers you published in recent years you'd given at Kalamazoo? Why didn't you publish them earlier?}

Yes. I was working very hard, teaching five courses a semester. And then in the mid-eighties, it became clear that if I didn't start publishing, I would never be promoted! [laughter] So that's when I started to work more seriously on charms. I think it was 1989 that I gave a paper on charms in Toronto. They didn't publish it, but Peter [Jones] was at that conference, and he asked a question there. He was the only other one who knew about the manuscript, Sloane 6. So that was how I met him.

And the only other connection I had with him was that occasionally he would come to give papers at a medical session that I went to at Kalamazoo. And he brought a text to me that was written on the Middleham Jewel. So we co-authored an article on the Middleham Jewel, which did not come out until $2000^{4}$ because we had problems communicating. Every time he sent me a draft, my computer officer had to open it, and every time I sent it, his computer officer had to open it. The reason he asked me to do that was to write about what it said on the jewel from the perspective of charms.

\section{J.R.: And eventually you moved to Cambridge...}

I retired in 2002 after twenty-seven years. And I moved here [Cambridge] in 2003. I had come to England to meet my new in-laws, and I came to London too and gave a paper at the Warburg Institute. [This was at the 'Conference Zero' of the group: Charms and Charming in Northern Europe, January 25th, 2003. A version of this paper was subsequently published as ${ }^{5}$ ]. So I was retired, and had no university support for travel to the States, for example. But I knew that I could travel east in a way that I could not travel west. And once I met the people who were working on charms in central and eastern Europe, I thought: These people will teach me. And that's what happened.

\section{J.R.: Teach you because they're dealing with living traditions often?}

Yes, and that made a real difference, because the first time I saw films of people doing charms, say, in a bath-house in Russia or in a house where the practitioner was taking on patients, and had people in their front room, lined up, and I could see the performance, that was enormously helpful in thinking about how the charms were performed. 
And the other turning point for my work on charms was when I signed up for a summer seminar on oral traditions in Missouri with John Miles Foley in 1989. And that made a big difference. He wanted me there as I looked at the Anglo-Saxon and the Latin. Coming out of that seminar, I wrote the article that came out in Oral Tradition ${ }^{6}$.

\section{J.R.: How might you describe your scholarly development in the last fifteen years or so?}

In the last fifteen years or so, it's been with manuscripts. That is to say, I've been trying to look for context for charms in the manuscripts. That's because I'm closer to the libraries now than I've ever been. I always came to the manuscripts for a few weeks in summer after I'd taught enough summer school to get the money. And then I would spend a week in Oxford, a week in Cambridge, and a week in London. But now I'm like Brer Rabbit in the thorn bushes, I'm living in the land of manuscripts. The old colleges have wonderful collections. The university library I spend an enormous amount of time in. And then I can get to London.

\section{J.R.: When you talk about context you mean immediate manuscript context?}

I would characterize it as trying to understand the place of the genre in manuscripts, as in my piece on the 'marginality' of charms 7 . The questions are: how do they relate to medical texts in manuscripts? how do they relate to religion in manuscripts of religion? and how do they relate to the context of their period? That is to say, are they in a vernacular text or in a Latin text? Are they in something that's being moved from one language to another?

\section{J.R.: So the impact you've been talking about modern-day fieldwork is a more diffuse influence on your work?}

I think this work is most meaningful to me when you come to think about performance. Because you realize that in performance you've got a lot more going on than just words. You've got the context of the need or problem, you've got the social event or maybe a private event, but it's a socially recognized event where some human need is being met - maybe fear, maybe sickness, maybe animal troubles, maybe to enhance a medicine. Or when you write a charm on a birth girdle, that's going into a specific set of circumstances - the anticipation of the difficulties of childbirth. All those represent living situations. 
So thinking about those situations is what people doing fieldwork brought to my medieval stuff. There's an interesting meshing there, because manuscripts become so philological - and they are, and you've got to track them - but when they are built of something like prayers, or charms, or recipes, then you know that they are having contact in some way or another with human situations.

\section{J.R.: What are you working on now and what paths do you envisage your scholarship taking in the future?}

I went away from Anglo-Saxon because I could not teach Anglo-Saxon in my university. So that's when I concentrated on Middle English, and I always kept up the Latin. Just lately, I have a paper I gave in Vilnius [at the ISFNR Congress in 2013] I mean to finish about literary texts that appear in vernacular charms in English, high-level bits of literary Latin incorporated into early medieval charms that go into the vernacular.

\section{J.R.: You'd see this as a continuation of your work on the context of charms?}

Yes. And the other thing I am supposed to be doing is putting together a collection of charms old and new in translation for students to look at the genre.

\section{J.R.: You have co-authored various works with your husband Peter Jones. How does that process work? And what benefits does it bring?}

The first one we did was on the Middleham Jewel, and that's been a paper picked up by archaeologists, like Roberta Gilchrist. And then we were asked to contribute to the encyclopedia that Sophie Page and Catherine Ryder published a couple of years ago on magic and medicine. Of course that involves charms and amulets ${ }^{8}$. And the other co-authored thing useful for charms studies was the one we did on performative rituals for conception and childbirth ${ }^{9}$. And that was a collaboration because Peter's department has been the Department of History and Philosophy of Science in Cambridge, which had a grant to work on reproduction from antiquity to now.

\section{J.R.: How does the collaboration work?}

The easiest way is to divide up the sections. He doesn't do Anglo-Saxon, so I do anything on early medieval. He got into charms and amulets through his study of medieval surgeons and doctors. So that's how we met. He gave me his charms from Fayreford, one of his physicians, when I was writing the article on 'Charms and Prayers in Theory and Practice'. This was not a 


\section{Jonathan Roper}

joint article, but I got material from him ${ }^{10}$. It was an important piece and it showed that high-profile scholastic doctors were using charms, something the rational medicine people had argued against. What collaborations with Peter have brought to my attention are medical manuscripts that I would not have looked at otherwise.

This work has been supported by the Estonian Research Council (grant project PGR 670)

\section{PUBLICATIONS MENTIONED IN THE INTERVIEW:}

${ }^{1}$ The Index of Charms: Purpose, Design, and Implementation. Literary and Linguistic Computing. 1991. 6,1: 59-63. [Co-authored with Suzanne Parnell]

${ }^{2}$ The Corpus of Charms in the Middle English Leechcraft Remedy Books. 214-237 in Roper, J., ed. Charms, Charmers and Charming: International Research on Verbal Magic. Houndmills: Palgrave Macmillan, 2009.

${ }^{3}$ The Arcus Charms and Christian Magic. Neophilologus. 1989. 73: 438-447.

${ }^{4}$ Middleham Jewel: Ritual, Power, and Devotion. Viator 2000. 31:249-290. [Co-authored with Peter Murray Jones].

${ }^{5}$ Charms in Medieval Memory. 59-90 in Roper, J., ed. Charms and Charming in Europe. Houndmills: Palgrave Macmillan, 2004.

${ }^{6}$ Latin Charms of Medieval England: Verbal Healing in a Christian Oral Tradition. Oral Tradition. 1992. 7,1: 116-142.

${ }^{7}$ The Marginality of Charms in Medieval England. 135-64 in Kapaló, James, Éva Pócs, and William Ryan, eds. The Power of Words: Studies on Charms and Charming in Europe. Budapest: Central European Press, 2013.

${ }^{8}$ Medicine and Magic. 299-311 in Page, Sophie and Catherine Rider, eds. The Routledge History of Medieval Magic. London and New York: Routledge, 2019. [Co-authored by Peter Murray Jones].

${ }^{9}$ Performative Rituals for Conception and Childbirth in England, 900-1500. Bulletin of the History of Medicine. 2015. 89: 406-433. [Co-authored with Peter Murray Jones]. ${ }^{10}$ Charms and Prayers in Medieval Medical Theory and Practice. Social History of Medicine. 2003. 16: 343-366. 